\title{
RELACIONES ENTRE POESÍA DIDÁCTICA Y FILOSOFÍA. HESÍODO, PARMÉNIDES Y EMPÉDOCLES
}

Maria Cecilia Colombani ${ }^{1}$

\begin{abstract}
Resumen
El proyecto del presente trabajo consiste en recuperar cierta función didáctica que parece darse en los vínculos que podemos establecer entre poesía y filosofía. En primer lugar transitaremos por algunos tópicos que se encuentran en la función didáctica de la poesía de Hesíodo en lo que concierne a su relación con su hermano Perses. En segundo lugar, revisaremos la función de la Diosa en el Proemio del Poema de Parménides. Finalmente, nos ubicaremos en el Poema de Empédocles para ver la dimensión didáctica que allí se despliega en el marco de los papeles que desempeñan Empédocles y un tal Pausanias.
\end{abstract}

\section{Palabras clave}

Poesía; Filosofía; didáctica; Hesíodo; Parménides; Empédocles.

\section{Resumo}

O projeto do presente trabalho consiste em recuperar certa função didática que verifica-se nos vínculos que podemos estabelecer entre poesia e filosofia. Em primeiro lugar, transitaremos por alguns tópicos que se encontram na função didática da poesia de Hesíodo no que diz respeito à sua relação com seu irmão Perses. Em segundo lugar, iremos analisar o papel da Deusa no Proêmio do Poema de Parmênides. Finalmente, nos localizaremos no Poema de Empédocles para ver a dimensão didática que ali se desempenha no marco dos papéis que desempenham Empédocles e um tal Pausânias.

\section{Palavras-chave}

Poesia; Filosofia; didática; Hesíodo; Parmêmides; Empédocles.

\footnotetext{
${ }^{1}$ Professora Doctora. Universidad de Morón, Argentina. email: ceciliacolombani@hotmail.com 


\section{Introducción}

El proyecto del presente trabajo consiste en recuperar cierta función didáctica que puede establecerse en los vínculos entre poesía y filosofía; siendo esta dimensión, sin duda, una de las marcas más significativas en el marco de la relación que proponemos indagar ${ }^{2}$.

Al relevar dicha función, trataremos, en primer lugar, de transitar algunos tópicos que pueden encontrarse en Hesíodo, sobre todo en Trabajos y Días, a partir de la función didáctica con que el poeta juega en relación con su hermano Perses. En segundo lugar, intentaremos recorrer la función de la Diosa en el Proemio del Poema de Parménides ante la llegada del iniciado, tras el viaje que emprendiera conducido por las Helíades, las luminosas hijas del Sol. Finalmente, nos ubicaremos en el Poema de Empédocles para desvelar la dimensión didáctica que allí se despliega en el marco del papel que desempañan Empédocles y un tal Pausanias, médico prestigioso de Agrigento, como aquél que es iniciado por el autor.

\section{Hesíodo de Ascra}

Si la Teogonía permite relevar ciertas marcas didácticas, a partir de la familiaridad de Hesíodo con las Musas, primeras maestras de alétheia; queremos concentrarnos en Trabajos y Días para relevar el tópico y ubicarlo en una relación más horizontal entre el poeta y su hermano (Detienne, 1986).

En primer lugar, la invocación a las Musas de la Pieria pone la misión hesiódica bajo el mismo amparo que tuviera en Teogonía y, por ende, bajo el mismo magisterio que las diosas le confieren para cumplir una misión de neto corte didáctico (Colombani, 2005). La ritualización discursiva, presidida por la autoridad de las Musas, confiere a la palabra de Hesíodo el mismo registro de poder que ellas mismas ostentan, al tiempo que cierra el discurso dentro del ámbito de una cierta sociedad de secreto, defendida y protegida en el marco de la poesía sapiencial, donde la dimensión didáctica domina la escena ${ }^{3}$.

\footnotetext{
${ }^{2}$ Cada vez que hagamos referencia a la poesía lo haremos desde una doble vertiente, su vínculo con la sabiduría y su relación con la transmisión de un saber prestigioso que exige una cierta ritualización del sujeto que habla, de la circunstancia en la que el mensaje se transmite y de la propia palabra requerida para ser enseñado. Triple excepcionalidad del mito, como aquel logos que constituye un primer intento de dar cuenta de lo real, íntimamente relacionado con el presente trabajo.

${ }^{3}$ En El orden del discurso, Michel Foucault analiza la relación entre discurso y poder y releva lo que él denomina el enrarecimiento de los sujetos, como mecanismo de control del discurso y para mostrar cómo el campo del mismo no tiene la misma permeabilidad por todos sus poros;
} 
Pensemos en Teogonía. Cuando las Moûsai se acercan al poeta, abriendo la distancia que los separa desde sus respectivos planos de ser, introducen la posibilidad de la mentira como nota constitutiva de su voluntad omnímoda:

¡Pastores del campo, triste oprobio, vientres tan sólo! Sabemos decir muchas mentiras con apariencia de verdades; y sabemos, cuando queremos, proclamar la verdad. Así dijeron las hijas bienhabladas del poderoso Zeus. $Y$ me dieron un cetro después de cortar una admirable rama de florido laurel. Infundiéronme voz divina para celebrar el futuro y el pasado y me encargaron alabar con himnos la estirpe de los felices Sempiternos y cantarle siempre a ellas mismas al principio y al final (Hes. Theog. 27-34)4.

Se trata de la dimensión de la palabra litúrgica, de registro mítico y sacralizado, que sale de la boca de las deliciosas maestras de verdad. Siempre de una palabra de alabanza, de un lógos theókrantos, que celebra a los Sempiternos Inmortales. En este marco, son ellas las que, desde un tópos ambiguo, saben decir muchas mentiras con apariencia de verdades (pseudéa), pero saben decir la verdad cuando les place.

La verdad siempre es patrimonio de los dioses y se juega en el marco de una lógica del don porque son ellos quienes eligen quién puede "verla" y cantarla. El don de videncia de un poeta inspirado y el canto que fluye de su boca constituyen la ecuación de una aproximación a la verdad. Ubica al poeta en el espacio de excepcionalidad ontológica que posee en la provincia de lo mágico religioso.

No obstante, esta palabra no siempre constituye un acercamiento a la verdad, ya que al presentarse en un escenario transido por la ambigüedad como nota constitutiva, puede opacarla; si las Moûsai pueden decir tanto la verdad como las cosas aparentes, entonces poseen la posibilidad de pronunciar las cosas verdaderas, pero también de ocultarlas, velarlas, cubrirlas y no permitir que la alétheia acontezca, brille, en el marco de una metáfora lumínica que tensa lo claro de su develamiento y lo oscuro de su velamiento.

La sabiduría, esa especie de filosofía popular (Gernet, 1981), se resuelve en el interior de esta lógica, de esta tensión entre lo verdadero y lo cubierto que, en el campo poético, dominado por un poeta vidente de registro hesiódico, toma la forma de una palabra sacralizada, ordenadora de lo real en su conjunto. En el plano oracular, presidido por la

por el contrario, hay zonas del discurso altamente protegidas y que quedan en manos de algunos privilegiados que lo ostentan a partir de ciertas cualificaciones propias. Entre esos mecanismos de control se encuentran las llamadas "sociedades de secreto".

${ }^{4}$ Todas las citas de Hesíodo se hacen según la traducción de Pérez Jiménez: 2000. 
terribilidad de Apolo (Colli, 1994), adquiere la forma de una palabra mántica, asociada a la manía como estado extra-ordinario, que debe ser de-velada y des-cubierta por el prophetés y que, en el ámbito de la soberanía, toma la forma de una sentencia divina de carácter inapelable, porque la justicia es siempre patrimonio de los dioses.

En Trabajos y Días el registro del magisterio está dado por la propia historia que pone en juego el poema; rasgos de carácter autobiográfico que tensan las relaciones entre Hesíodo y Perses ubican al primero en el lugar de la prudencia, sophrosýne, el esfuerzo, y el trabajo, como marcas de la areté, frente a su hermano Perses que, en el polo opuesto de la tensión, resulta ser el contra-modelo antropológico-cultural.

La capacidad didáctica de Hesíodo está legitimada por sus condiciones morales, que contrastan en un juego de espejos invertidos con la condición moral de su hermano. Desde esa diferencia de actitud frente a la vida es que Hesíodo afirma: "yo trataré de poner a Perses en aviso de la verdad" (Hes. Op. 10-11).

Retorna así un rasgo de lo que fuera el soporte didáctico de Teogonía: hablar o actuar en nombre de la verdad, ya que a él las deliciosas hijas del Padre le han dicho las cosas verdaderas, tá alethéia, más allá de que puedan pronunciar cosas engañosas, tá pseudéa, con apariencia de verdades $^{6}$. La misión didáctica de Hesíodo está avalada por estar en la verdad de las cosas, aletheiuein, y actuar en consecuencia, advirtiendo a su hermano, en gesto didáctico, lo que no puede ser de otra manera: “ $\mathrm{OOh}$ Perses, grábate tú esto en el corazón!" (Hes. Op. 28).

El magisterio poético está sostenido por la estrecha familiaridad con las Musas, a quienes ha invocado al iniciar el canto, y lo habilitan a narrar, mythéo, aquellos mythoi, en tanto historias significativas, sagradas, verdaderas y arquetípicas ${ }^{7}$. Desde ese poder-saber, Hesíodo se dirige a Perses para ofrecerle el relato fundacional: "Ahora si quieres te contaré

\footnotetext{
${ }^{5}$ Hes., Op. et di., 10-11.

${ }^{6}$ A partir de la obra de Gigon, tanto de Los orígenes de la filosofía griega como de Problemas fundamentales de la filosofía griega, la lectura que ha hecho la crítica, de la cual nos nutrimos y seguimos como marco interpretativo, ha ubicado a Hesíodo en esa zona oscura, de fronteras imprecisas entre poesía y filosofía, propia de la Grecia arcaica; asimismo, ha trabajado los núcleos filosóficos presentes en Teogonía como relato emblemático de la totalidad. El problema del ser, del todo, del origen, de la verdad y de la transmisión de la verdad han sido los hilos que Gigon ha encontrado para hilvanar el tapiz del Hesíodo-filósofo.

${ }^{7}$ Mircea Eliade en La estructura de los mitos enuncia estos cuatro adjetivos que le otorga al mythos, luego de haberlo desprendido de la visión decimonónica donde el relato mítico queda asociado a la idea de un pensamiento en falta, salvaje e imperfecto, propio de una etapa adolescente de la humanidad. Eliade restituye al mito a su lógica compleja, ubicándolo a la par de otros sistemas de pensamiento que dan cuenta de la complejidad de lo real.
} 
brevemente otro relato, aunque sabiendo bien -y tú grábatelo en el corazón - cómo los dioses y los hombres mortales tuvieron un mismo origen" (Hes. Op. 106-108) ${ }^{8}$.

De manera semejante, la autoridad que le confieren tanto la presencia de la verdad como las condiciones morales que lo asisten, le permiten dirigirse a los reyes en una misma actitud didáctica. El magisterio poético recibido por las Musas le permite denunciar y enfrentar el poder de quienes detentan la autoridad política en la aldea; una autoridad devaluada en términos morales a partir de las prácticas de los dorophágoi. El enfrentamiento en términos discursivos que el poeta realiza está legitimado, una vez más, por su autoridad moral, que lo habilita a ser un maestro de alétheia. La dimensión didáctica de matriz correctiva se materializa entonces en advertencia:

iOh reyes! Tened en cuenta también vosotros esta justicia; pues de cerca metidos entre los hombres, los Inmortales vigilan a cuantos con torcidos dictámenes se devoran entre sí, sin cuidarse de la venganza divina (Hes. Op. 249-252).

Más allá de este desafío de impacto político, el relato emblemático que despliega el magisterio hesiódico está dirigido a su hermano. Su dimensión didáctica está directamente asociada al saber que posee sobre las cuestiones más prácticas de la vida: "Yo que sé lo que te conviene, gran necio Perses, te lo diré: de la maldad puedes coger fácilmente cuanto quieras; llano es su camino y vive muy cerca" (Hes. Op. 287-289).

Sólo elegimos esta advertencia como ejemplo de toda una serie de consejos, recomendaciones, exhortaciones con las que Hesíodo se dirige a su hermano en actitud correctora y transformadora. Para lograr alguna metamorfosis sobre la conducta de Perses es necesario intentarlo desde un espacio didáctico, aun frente a la cercanía de edades entra ambos hermanos.

No obstante, cabe aclarar que la dimensión didáctica va más allá de las fronteras de su propio hermano. La organización del dispositivo laboral, tal como de ello da cuenta la obra, sus recomendaciones, el corpus de saberes desplegados, convierten al poema en un logos abierto a todos los integrantes de la comunidad de labradores. Su magisterio es el tópos a partir del cual se edifica la rutina laboral, que organiza la vida individual y la identidad del colectivo de labradores. Hasta aquí una primera relación entre poesía y filosofía, leída desde un andarivel didáctico, aclarando que nuestra perspectiva ubica a Hesíodo como un primer filósofo.

\footnotetext{
${ }^{8}$ Siguiendo a Pérez Jiménez, se acepta la corrección de A. García Calvo.
} 


\section{Parménides de Elea}

En segundo lugar nos proponemos un recorrido por el Proemio del poema de Parménides desde la misma actitud didáctica. Parménides floreció en 500 a. C. Su presencia constituye un hito fundamental en la llamada filosofía presocrática, en el marco de la primera especulación naturalista; aunque su importancia y peculiaridad radica precisamente en apartarse de esa tradición, que hace del estudio de la naturaleza el objeto de investigación, para iniciar otro atajo dentro del pensamiento, de marcado sesgo metafísico, a partir de la preocupación por el Ser.

No obstante, no es este aspecto de la filosofía de Parménides el que queremos abordar, sino una cierta relación con la tradición poética que se exhibe en el Proemio y, desde allí, rescatar la presencia de lo femenino en ese contexto de magisterio; lo cual parece vincularlo con Hesíodo, donde la iniciación poética incluye la presencia de las Musas como nota dominante y el dispositivo didáctico como acontecimiento filosófico.

El Proemio posee un tono poético y es una especie de introducción que abarca los treinta y dos versos que constituyen el fragmento, al tiempo que posee características bien diferentes del resto del Poema (Cordero, 2005); se inserta en un fondo mítico religioso, que destaca del tono argumentativo posterior. Múltiples imágenes se recortan de las huellas de la tradición poética arcaica desde donde podemos tender líneas de intersección.

El fragmento 1 relata la experiencia de un viaje del cual el propio Parménides es protagonista y narrador, similar a la experiencia hesiódica, describiendo una situación de iniciación semejante, en la que la presencia femenina es determinante. Tanto a uno como a otro, las diosas los llevan, los trasladan de un tópos a otro como forma de iniciar un viaje teleológico cuyo fin último es la verdad.

Son dos los registros femeninos que podemos rescatar. Del verso 1 al 23 la descripción del viaje ofrece la imagen de un carro tirado por dos caballos y conducido por unas jóvenes doncellas, las Helíades, hijas del Sol${ }^{9}$. El carro debe traspasar las puertas del Día y de la Noche para terminar arribando a la morada de una diosa, tensionando la díada oscuridadclaridad; de la noche vienen las jóvenes aurigas y hacia el día se

\footnotetext{
${ }^{9} \mathrm{El}$ carro es tirado por caballos, aunque sin la presencia de un auriga; son precisamente las jóvenes doncellas las que tiran de él, mostrándoles a las yeguas el camino de un viaje donde son ellas las que parecen conocer el camino, posicionándose en un lugar de saber. Las doncellas han puesto al joven en el sendero de la divinidad porque conocen el mismo. Conducción y saber parecen ser las notas de las hijas del Sol.
} 
encaminan ${ }^{10}$. A partir del verso 24 hace su aparición el segundo elemento femenino: la Diosa, de marcada matriz didáctica, que completará la revelación. Interpretamos que la guía de las jóvenes Helíades constituye un primer momento de la iniciación-revelación, ya que conocen el camino por dónde conducir al joven.

La Diosa, cuyo nombre desconocemos, recibe a Parménides y sigue en su boca la totalidad del Poema, en un despliegue de saber que ella parece encarnar. Luego del saludo inicial, la Diosa da la bienvenida a Parménides, al tiempo que lo felicita por haber alcanzado ese lugar desde el territorio de los mortales. Por último, entre los versos 28 y 31, la Diosa da muestras de su saber, revelándole al recién llegado lo que el resto de los mortales no conocen.

Yo te alejo...de aquello (el camino de investigación) sobre lo que yerran los mortales de dos cabezas, que nada saben, pues la insensatez dirige en sus pechos el vacilante pensamiento. $Y$ se agitan de aquí y allá, mudos y ciegos, tontos; muchedumbre de insensatos, para quienes el ser y el no ser les parecen lo mismo y no lo mismo, y el camino de todas las cosas se halla en direcciones opuestas (Parm., De nat. fr. 6; versos 4-9)11.

La Diosa se dirige al joven con gesto didáctico advirtiéndole del corazón mismo de la verdad del Ser. La advertencia se refiere a los hombres de dos cabezas que se fían del testimonio de los sentidos, donde la multiplicidad y la mutabilidad del devenir exhiben el cruce del ser y el no ser.

Más allá de este mensaje, que no es nuestra intención analizar, lo que sí sorprende es la disimetría estatutaria entre la Diosa, que parece conocer la verdad y poder enseñarla, y los hombres de dos cabezas, destinados a aprender. En este punto la relación con Hesíodo resulta significativa porque un mismo recurso pone a ambos en un plano de semejanza. Ambos colocan la verdad en boca de la divinidad. Son las diosas, las Musas Heliconíadas, en el caso de Hesíodo y esta diosa innominada, en el caso de Parménides, las que ostentan el poder de decir la verdad, de transmitirla con gesto didáctico, y corresponde a los hombres, aquellos "pastores del campo, triste oprobio, vientres tan sólo», o bien los «mortales de dos cabezas", escucharla.

\footnotetext{
10 Surge una notación lumínica que nos permite territorializar a las doncellas en el marco de una zona lumínica. Las Helíades son hijas de la Luz y abandonan precisamente las mansiones de la Noche, tensionando la díada Noche-Día, Luminosidad-Tenebrosidad. Resultan, como las Musas, divinidades de signo luminoso, de registro diurno, emparentadas con elementos luminosos como el sol o el propio Zeus en su condición de Padre luminoso.

${ }^{11}$ La totalidad de las traducciones de los fragmentos analizados pertenece a R. Mondolfo: 1980; en este caso, p. 78.
} 
Pero tú, aleja tu pensamiento de esta vía de investigación y que no te empujen en ella el hábito empírico de dejar dominar el ojo desprovisto de un fin, y el oído rumoreante y la lengua. Pero juzga con la razón, la prueba tan discutida, afirmada por mí (Parm, De nat., 1, 33-37 = 7, 2-5 D.-K.)12.

Advertimos el tono didáctico-exhortativo de la Diosa, que ostenta la autoridad que su poder le confiere para recomendarle al joven alejar su pensamiento de la vía impracticable. Reafirma el valor de la razón como único criterio válido de investigación y vuelve a insistir en tono aleccionador:

Vamos, yo te diré - y escuchando el discurso consérvalo en ti- las dos únicas vías de investigación que se puedan concebir. La una, que (el ser) es y no puede no ser: ésta es la vía de la Persuasión, porque se halla acompañada de la verdad; la otra, que no es y que es necesario que no sea: y éste, te digo, es un sendero en el que nadie aprenderá nada (Parm., De nat. 1, 33-37 = 2, 2-5 D.-K.).

La Diosa sigue ejerciendo su magisterio, al tiempo que despliega la verdad de la única vía posible. De su boca sale la verdad como también salían las cosas verdaderas de la dulce voz de las Musas en su primer desarrollo didáctico.

La Diosa marca la diferencia estatutaria entre ella y el recién llegado; le advierte que le ofrecerá un discurso en actitud de entrega de su saber, pero que él debe conservarlo, en actitud receptiva, tal como se juega la relación entre maestro y discípulo. Le ha mostrado las dos vías, la del ser y la del no ser como una antítesis irreconciliable y con ello lo inicia en la vía del conocimiento.

Es ese conocimiento el que la eleva por encima del joven que acude a ella con gesto iniciático. Es la ecuación saber-poder la que se despliega en la escena didáctica y la Diosa insiste en su registro de autoridad

Pues tú no podrás conocer el no-ser -lo cual no es posible ni podrías expresarlo (4, 78). Es menester decir y pensar que el ser es, pues es posible que él sea, pero la nada no es posible: esto es lo que te ruego que consideres. Pues yo te alejo de esta primera vía de investigación (Parm., De nat. 4, 7-8 +6, 1-3).

La Diosa dictamina qué se puede conocer y qué no, qué se puede decir y qué no $\mathrm{y}$, en tono exhortativo y amigable, le pide a su interlocutor que considere esa verdad. Los fragmentos y el énfasis que hemos puesto en la actitud de la Diosa acercan a Parménides a la tradición poética inscrita en el magisterio que venimos rastreando. Poema y divinidad comparten un mismo registro didáctico, en el que las divinidades cumplen una nítida

\footnotetext{
${ }^{12}$ El texto de referencia de los presocráticos sigue siendo la edición de Diels-Kranz por lo tanto indicamos la correspondencia en los fragmentos de D.-K.
} 
función de enseñanza, extensiva al orden del poema que ellas mismas instituyen desde su saber.

Son las Musas, las divinas hijas de Zeus y Mnemosýne, las que una vez enseñaron a Hesíodo su bello canto, incapaz de alcanzar esas verdades sin su auxilio; ellas, las únicas maestras capaces de decir la verdad. De un modo análogo, la Diosa da la bienvenida a quien nada sabe, con gesto amable, acogedor, y se encarga didácticamente de la revelación como acto fundacional del conocimiento del Ser, al tiempo que queda, en ambos casos, delineada la binariedad de planos (Gernet, 1981: $15 \mathrm{ss}$ ), el humano y el divino, en el marco de la alianza saber-poder. La tríada conducciónrevelación-magisterio es el símbolo mismo del gesto didáctico y de la luminosidad que embarga a ambos Proemios como lógoi iniciáticos.

Cuando las jóvenes abandonan la Noche para ingresar a la Luz, se quitan el velo que las cubría. Nueva marca de la luminosidad que la iniciación pone en juego y que privilegia el par de tensiones que ambos poemas parecen delinear en sus despliegues cartográficos: lo velado y lo develado, lo cubierto por el velo que las doncellas traen de las Mansiones de la Noche, y lo des-oculto que implica la acción de retirarse el velo. La quita del velo parece marcar el cambio de topoi y la acogida de la Diosa será el momento del des-ocultamiento. Estamos sobrevolando el campo lexical del término alétheia. El velo acompaña la estancia de las doncellas en el ámbito oscuro, mientras que la salida implica la acción de desocultamiento; de modo análogo, el don de las Musas Heliconíades constituye el pasaje del poeta vidente a otro tópos en tanto condición antropológica. Una misma marca, un mismo gesto asociado a un viaje iniciático que es, sobre todo, un gesto didáctico.

\section{Empédocles de Agrigento}

En tercer lugar queremos transitar algunos aspectos del pensamiento de Empédocles guiados por el mismo proyecto por el que venimos transitando. No nos mueve analizar críticamente el discurso del filósofo, sino situarnos en su Poema, para anudar, una vez más, las relaciones entre poesía y filosofía, y detectar, dentro de lo posible, los tópicos que aparecieron en los dos pensadores anteriores.

Oriundo de una rica ciudad de Sicilia, Acragante, es posible situar su nacimiento en el $494 \mathrm{y}$ su muerte hacia el 434. Tal como sostiene A. Bernabé Pajares,

Con Empédocles regresamos a un mundo filosófico y literario más próximo al de Parménides, con una implicación íntima entre filosofía y religión, característica del sur 
de Italia, y con el verso épico y los recursos tradicionales como instrumento de expresión (2008: 181).

De los fragmentos conservados, ya que el original se perdió, se puede observar su conocimiento y admiración por Parménides, así como el conocimiento de los físicos jónicos. Escribió dos poemas, cuya unidad es tema de discusión, uno referido a una suerte de ciclo cósmico y otro dedicado a la transmigración de las almas, a partir de las sucesivas purificaciones, por lo que recibe precisamente este nombre. Tal como sostiene N. Cordero

nada impide que ambos textos formen parte de un poema único, pues Empédocles, como casi todos los primeros filósofos, encaró la realidad como un todo, y la vida humana formaba parte de ese todo (2008: 97).

Básicamente, postula la existencia de cuatro componentes originarios que existen desde siempre ya que no hay noción de creación, siendo el equilibrio cósmico el juego de tensiones que mantienen esas cuatro raíces, a partir de la existencia de dos principios de carácter opuesto: el Amor y la Discordia, pensadas desde una analogía con la vida humana. Desde otra perspectiva también esos elementos aparecen en Hesíodo, como Eros y Eris, para dar cuenta, en primer lugar, de un amor primigenio como fuerza de atracción que une y constituye uno de los cuatro primerísimos en la cosmogonía hesiódica y, en segundo lugar, de la discordia como aquello que separa y rompe el equilibrio.

Tal como afirma Cordero

Empédocles dirá que las cuatro cualidades son el origen de todo y por esa razón utilizará la palabra "raíces" para nombrarlas (una vez más, un término relacionado con la visión dinámica de la physis por parte de los griegos. Recuérdese que physis significa lo que está creciendo (2008: 97).

Cuatro elementos que, simbólicamente, son identificados con imágenes míticas; ni agua, ni fuego, ni tierra, ni aire, sino Zeus, el brillante, Hera, quien da la vida, Aidoneo y Nestis:

Pareciera que Zeus representa al fuego (pues es brillante), Hera la tierra (que es tradicionalmente la tierra madre), Nestis, divinidad siciliana, parece representar el agua; sólo queda Aidoneo como imagen del aire, ya que su nombre significa algo así como "el invisible", y al aire no se lo ve (2008: 97).

También las dos fuerzas opuestas son representadas con imágenes míticas como punto que se debe considerar en la alianza entre poesía y filosofía. Así, la fuerza que une es Afrodita, Amistad, philótes; mientras la que separa es Discordia, néikos, Combate, Lucha. 
Pasemos ahora a analizar la dimensión didáctica que el poema despliega para establecer los puntos de contacto. Coincidimos con Bernabé Pajares cuando afirma:

Literariamente, Empédocles es un consumado poeta que domina las fórmulas y los recursos homéricos, a la vez que muestra una serie de aspectos nuevos, como el gusto por la palabra rica, el término raro y, sobre todo, por la ambigüedad buscada como efecto -lo que, dicho sea de paso, constituye un tormento para el traductor-. Su afición por la metáfora -brillante, rotunda- suscita la crítica de Aristóteles, que cree que este tipo de lenguaje poético se aviene mal con la, para él, necesaria claridad de la expresión filosófica, lo cual, si bien es cierto para la época del estagirita, no lo es tanto para la de Empédocles, una época en que las fronteras entre lo racional y lo poético, entre lo místico y lo filosófico, no se habían trazado aún con nitidez (2008: 183).

En este marco de fronteras poco claras, pasaremos a analizar algunos fragmentos significativos para nuestro trabajo. En primer lugar, rastrearemos la función de las Musas que, como en Hesíodo, hacen su aparición en el Poema. De la mano de su presencia, aparece la disimetría de planos entre lo humano y lo divino.
Alejad, pues, dioses, de mi lengua el extravío de esa gente y encauzad por mi boca piadosa un límpido hontanar.
$Y$ a ti, virgen de la memoria fértil, Musa de albos brazos, te suplico; lo que es lícito que oigan los seres de un día, envíamelo, conduciendo desde las moradas de la Piedad el carro dócil a la rienda (Emped., De rer. nat. 2 = 3 D.-K.).

La invocación a las Musas se da de manera análoga a lo que aparece en Hesíodo, donde el poeta se refiere a las diosas en el marco de su precariedad ontológica. Los "pastores del campo, triste oprobio", saben de la imposibilidad de conocer lo que fue, lo que es y lo que será a partir de su condición de simples mortales. Son las Musas las únicas que pueden asistirlo y por ello constituyen la condición de posibilidad del conocimiento.

En el caso de Empédocles, quien habla les pide a los dioses que lo encaucen en el camino correcto para evitar el desvío de aquellos mortales que, como él, pueden equivocar la senda. Acto seguido se dirige a la Musa, reconociéndole, como en Hesíodo, su memoria prodigiosa, herencia de su gloriosísima madre, Mnemosýne. La Diosa tiene los mismos condimentos que aparecieran en Hesíodo, su condición virginal, su memoria sacralizada, los albos brazos, signos de su juventud, como la tersa piel de las Musas Heliconíades.

Recordemos el inicio de Teogonía: 
Comencemos nuestro canto por las Musas Heliconíadas, que habitan la montaña grande y divina del Helicón. Con sus pies delicados danzan en torno a una fuente de violáceos reflejos y al altar del muy poderoso Cronión. Después de lavar su piel suave en las aguas del Permeso, en la fuente del Caballo o en el divino Olmeo, forman bellos y deliciosos coros en la cumbre del Helicón y se cimbrean vivamente sobre sus pies (Hes. Theog. 1-9).

Son ellas las que pueden decirle lo que un simple mortal puede oír, convirtiéndose así en el auxilio de los hombres transidos por el tiempo y la muerte. Las similitudes son notorias y el carácter didáctico de las Musas queda nítidamente expresado

iSalud, hijas de Zeus! Otorgadme el hechizo de vuestro canto. Celebrad la estirpe sagrada de los sempiternos Inmortales, los que nacieron de Gea y del estrellado Urano, los que nacieron de la tenebrosa Nýx y los que crió el salobre Ponto. Decid también cómo nacieron al comienzo los dioses, la tierra, los ríos, el ilimitado Ponto de agitadas olas y, allí arriba, los relucientes astros y el anchuroso cielo. [...] Inspiradme esto, Musas, que desde el un principio habitáis las mansiones olímpicas, y decidme lo que de ello fue primero (Hes. Theog. 104-115).

Otorgadme. Inspiradme. Decidme. El subrayado de los verbos hace hincapié en el pedido de auxilio para conocer aquello que fue en un principio ${ }^{13}$. Sin ese auxilio nada puede ser conocido, confiriéndole así un cierto matiz religioso al conocimiento, lo cual hace difícil el límite preciso entre poesía y filosofía. El magisterio femenino es claro y las Musas constituyen las maestras de una verdad de difícil acceso.

Desde otro ángulo, la imagen del carro se emparienta con la tradición parmenídea, en el punto en que el viaje iniciático supone el desplazamiento desde un tópos a otro en el orden del conocimiento. Si bien no aparece la imagen del carro, sí está presente la metáfora del viaje en Hesíodo porque, de algún modo, la posesión-inspiración, enmarcada en el campo lexical de verbo katochéo, constituye una especie de viaje al más allá. La dimensión didáctica del fragmento es incontrastable y se inscribe nítidamente en la tradición que venimos explorando.

Así pues, si a instancias de alguno de los seres de un día, Musa inmortal, tuviste a bien que nuestros desvelos hollaran tu interés, asiste ahora, una vez más, Calíope, a este suplicante, en su intento de exponer un relato cabal sobre los dioses (Emped. De rer. nat. $3=131$ D. - K.).

El nuevo fragmento refuerza la dualidad de planos; los «seres de un día» y la divinidad ocupan como siempre, espacios diferenciados: unos solicitan asistencia mientras la Musa de "albos brazos" la otorga a

${ }^{13}$ O. Gigon, cf. n. 9

Revista Heródoto, Unifesp, Guarulhos, v. 2, n. 1, Maio, 2017. p.165-182 - 176 - 
voluntad. El auxilio solicitado es el expreso pedido para narrar un relato sobre los dioses, nuevo punto de contacto con la tradición hesiódica, del cual dan cuenta los versos escogidos.

La exhortación didáctica retorna al invitar al interlocutor a respetar la palabra de la Musa como fuente de verdad y autoridad: "En los miserables es costumbre no dar crédito a la autoridad. Tú en cambio, tal como te exhortan las garantías de la Musa, aprende, tras haber desmenuzado en tu fuero interno mi argumentación"(Emped. De rer. nat. $6=4$ D.-K.).

El fragmento no sólo refuerza la distancia entre mortales e Inmortales, sino que además define dos campos antropológicos: el de los hombres incapaces de dar crédito a la legitimidad y autoridad divina, y los que sí pueden hacerlo a partir del reconocimiento del poder de la Musa.

Pensemos a continuación algunos aspectos propiamente doctrinales a partir de la relación entre quien ocupa la función de transmisión y quien acude a recibir el conocimiento, en el marco de una pareja pedagógica, donde uno transmite un mensaje y otro se convierte en el receptor del mismo.
$Y$ es que angostas son las mañas que por los miembros se extienden y muchas las vilezas que acucian y embotan las meditaciones.
Tras haber observado en el curso de sus vidas una parte miserable, efímeros como el humo se echan a volar, arrebatados, convencidos tan sólo de aquello que cada uno se encontró en su vagar de un lado a otro, aun cuando cada uno se jacta de haberlo descubierto todo.
iA tal extremo no son cosas observables ni audibles por los hombres ni abarcables por su inteligencia! Así que tú, ya que hasta aquí te has acercado, sabrás, pero no más que lo que el mortal entender puede alcanzar (Emped. De rer. nat. 1 = 2 D. $-K$.$) .$

El fragmento corresponde al inicio del poema y es de neto corte antropológico porque pone en juego distintas tensiones. En primer lugar la distinción entre los sentidos y la razón. Se enfatiza la idea de la ignorancia humana, que en este caso está asociada a la incapacidad de los mortales para conocer la realidad a través de los sentidos como fuente de conocimiento. En este marco,

Empédocles como filósofo inspirado, posee conocimientos superiores que le han sido revelados, ya que la Musa habla por su boca (frs. 2-3), por lo que muestra un religioso respeto para no mancillar el ámbito de lo divino, en contraposición a quienes persiguen un éxito fácil aun a costa de hablar con temeridad de lo que no es debido (fr. 5) (Bernabé Pajares: 2008, 184). 
El cierre del fragmento recupera la idea de movimiento-viaje que venimos rastreando porque el discípulo se ha acercado hasta el maestro inspirado para saber aquello que su condición antropológica le permitirá conocer.

Un segundo tópico de interés resulta su teoría de los elementos. Recordemos que no es nuestra intención el análisis del pensamiento de Empédocles, sino ver cómo su teoría toma cuerpo en el marco de una transmisión de conocimiento que supone un maestro, el filósofo-poeta, y un discípulo, Pausanias. En efecto, el autor se dirige didácticamente a un tal Pausanias, nombrado en el fragmento 4 (1 D.-K.), a quien exhorta a escuchar, en la escena canónica de quien transmite un mensaje y de quien es invitado a oír: "Oyeme tú, Pausanias, hijo del sabio Anquito" (Emped. De rer. nat. $4=1$ D.-K).

La primera formulación de los cuatro elementos posee notorias connotaciones míticas y responden a un fondo mágico religioso que lo emparienta con la tradición: "Las cuatro raíces de las cosas todas escucha lo primero cuáles son: Zeus resplandeciente, Hera dispensadora de la vida, así como Aidoneo y Nestis, que con sus lágrimas empapa el mortal hontanar" (Emped. De rer. nat. 7 = 6 D.-K.).

Más allá de los cuatro elementos,

Lo que es nuevo en Empédocles es que, mientras para todos sus antecesores estos contrarios eran resultado de la evolución de un solo elemento originario, para él los cuatro, aire, tierra, agua y fuego, son igualmente originarios, ingénitos $e$ imperecederos, es decir, con las propiedades del ser parmenídeo, excluida la unidad. En la primera designación (fr. 7) las raíces reciben nombres divinos, lo que se aviene perfectamente con su ser eterno (Bernabé Pajares, 2008: 185).

Siguiendo las líneas de continuidad y ruptura, si nos permitimos relacionar el tópico con la cosmogonía hesiódica, los cuatro elementos tienen puntos en común con el poeta beocio, donde tà prótista, los cuatro primerísimos, Caos, Gea, Tártaro y Eros son idénticamente originarios, sin que ninguno nazca del anterior, devolviendo su condición de inengrendrados. Tal como hemos sostenido, indagando el trazo de un Hesíodo filósofo,

El primer elemento a considerar es que Hesíodo presenta cuatro elementos primeros, primerísimos, sin aparente relación entre sí, y menos aún, sin relación amorosa alguna; no hay cópula, ni abrazo amoroso, ni contacto que sugiera el orden del discurso posterior, donde sí el elemento erótico parece jugar los destinos de las descendencias divinas. Allí están los cuatro primerísimos, tà prótista, sin que ninguno derive de otro (Colombani, 2016: 112). 
No obstante, lo que queremos remarcar es nuevamente la exhortación a escuchar la revelación, reforzada en el fragmento siguiente, al referirse al relato, objeto de escucha:

Doble es la historia que voy a contarte. Pues una vez creció para ser uno, de múltiple que era; otra, por el contrario, de uno que era, se disoció para ser múltiple.

Doble es el nacimiento de los seres mortales, doble su destrucción; pues el primero lo genera y lo destruye la concurrencia de las cosas todas y el otro, al disociarse éstas de nuevo, echa a volar, una vez criado.

$Y$ estas transformaciones incesantes jamás llegan a su fin, unas veces por Amistad concurriendo en uno todos ellos, otras, por el contrario, separados cada uno por un lado por la inquina de Odio. De esta forma, en la medida en que lo uno está habituado a nacer de lo múltiple y en la medida en que a su vez, al disociarse lo uno, lo múltiple resulta, en ese sentido nacen y no es perdurable su existencia.

Mas en la medida en que estos cambios incesantes jamás llegan a su fin, en ese sentido son por siempre inmutables en su ciclo.

Así que escucha mi relato, pues el aprendizaje acrecienta el entender (Emped. De rer. nat. 8, 1-14 = 17, 1-14 D.-K.).

Independientemente del contenido, meollo de la teoría de Empédocles, nos interesa remarcar el principio y el final donde se alude al relato prestigioso dirigido a un tú que opera como interlocutor, como lo es Perses del relato de Hesíodo en Trabajos y Días, o el joven del mensaje de la Diosa en Parménides. En todos los casos, el discurso circula en forma de relato sapiencial, cargado de un poder que, en el caso de Hesíodo tiene el poder potencial de transformar la conducta de su hermano, y en el de Parménides y Empédocles, la posibilidad de conocer el problema de la verdad del ser.

Los giros discursivos que denotan la relación didáctica no cesan y podemos relevar algunas expresiones que refuerzan la imagen: "Como ya dije antes, al declarar los lindes del relato", "Y otra cosa te diré", "Vamos pues, observa como prueba de las charlas del principio lo siguiente", "Tenlo con toda claridad presente, pues de origen divino es el relato que has oído", "Mas yo voy a tomar de regreso por la senda de los cantos que recité al principio"; son algunas de las expresiones que dan continuidad a la trama discursiva e hilvanan una relación inscrita en la dimensión del magisterio como modelo de transmisión de la verdad.

A modo de cierre del presente apartado, queremos anudar el valor del conocimiento con la vida práctica, sumado a un escenario descrito de intensa huella poética, como modo de urdir la trabazón entre filosofía y poesía: 
Cuantos remedios hay contra los males y un refugio contra la vejez vas a aprenderlos, pues sólo para ti daré término a todo esto. Harás cesar la furia de los vientos incansables que por cima de la tierra se abaten y arruinan con sus soplos los sembrados. Y a tu vez, si lo deseas, resucitarás compensadoras brisas y dispondrás tras la lúgubre lluvia un tiempo seco bienvenido para los hombres, y dispondrás también, después de la sequía veraniega, fluidos que moran en el éter, alimento de árboles, y sacarás de Hades el vigor de un varón fallecido (Emped. De rer. nat. $101=$ 111 D.-K.).

El fragmento 101 es elocuente en la pretensión del maestro en relación con su discípulo. Tal como sostiene Bernabé Pajares, con quien coincidimos,

pretende que su discípulo Pausanias será capaz, si signe sus enseñanzas, de una serie de realizaciones maravillosas. Tal pretensión contribuyó sin duda no poco a su fama de brujo. Incluso en época moderna se ha desarrollado la interpretación de asimilarlo al tipo del chamán, que por medio del éxtasis se pone en contacto con los cielos y los infiernos y adquiere así sus secretos y poderes contra la muerte incluso (2008: 199).

Es éste un tópico incluso muy importante en la inscripción de Empédocles a la tradición que traba poesía y filosofía. Como juego de semejanzas, podemos pensar en la figura legendaria de un purificador como Epiménides: “Esta es la instalación de un personaje como Epiménides de Creta. En efecto, la alétheia que Epiménides de Creta tiene el privilegio de ver con sus propios ojos es la llanura de alétheia que el alma del iniciado aspira a contemplar" (Detienne, 1986: 18). Incluso, en el marco de esta configuración religiosa, alétheia no sólo es complementaria de Mnemosýne, sino también de Díke, ya que no hay distancia entre lo verdadero y lo justo y el propio Epiménides, un chamán griego, "va a pleno día a la gruta de Zeus Diktaios, y permanece allí soñando durante numerosos años, conversa con los dioses y habla con Alétheia y Dike" (Detienne, 1986: 43). La imagen evoca la familiaridad del maestro religioso con los dioses. Allí está Epiménides "conversando con la divinidad, dando testimonio de la familiaridad con ese mundo extraño al humano" (Colombani,:2016: 104 ss). Esta es la tradición en la que bebe la inscripción de un Empédocles chamán, poeta y purificador, dotado del mismo don de videncia que un maestro de verdad en términos de $\mathrm{M}$. Detienne.

Siguiendo esta línea, coincidimos con J. P. Vernant al referirse al vínculo entre ambos:

En pleno siglo V, Empédocles testimonia la vitalidad de este modelo de mago, capaz de dirigir los vientos, de rescatar a un difunto del Hades y que ya no se presenta a sí mismo como un mortal, sino como un dios (2001: 78). 
La singularidad de estas figuras, como Epiménides o Empédocles, radica en que su disciplina, su modo de vida, sus ejercicios espirituales, sus técnicas de ascesis, hablan de una sumisión a Apolo como arquetipo de luminosidad; un Apolo Hiperbóreo, modelo del dios chamán. Hay en estas figuras un elemento sobrenatural, extraño a la vida común de los mortales, un sujeto excepcional como lo son el poeta, el adivino o el rey de justicia en el marco de la provincia de lo mágico religioso.

\section{Conclusiones}

El proyecto del presente trabajo ha consistido en relevar una peculiar dimensión didáctica que parece constituir un punto clave e insoslayable en los vínculos que se pueden rescatar entre poesía y filosofía. En primer lugar, transitamos algunos tramos de la obra de Hesíodo, sobre todo en Trabajos y Días, para advertir cómo desempeña el poeta la función didáctica en la relación con su hermano Perses, que exige un trazo de corrección moral.

En segundo lugar, nos instalamos en el magisterio que la Diosa sostiene en el Proemio del Poema de Parménides, acogiendo al iniciado, tras el viaje de iniciación de marcado sesgo femenino, conducido por las luminosas hijas del Sol. La presencia de la Diosa fue capital a la hora de relevar la función didáctica que transmite el camino de la verdad como télos posible y deseado.

Finalmente, nos ubicamos en el Poema de Empédocles para rastrear la misma dimensión didáctica, en el marco de un gesto de iniciación semejante que se da entre Empédocles y Pausanias. Hasta este punto nos hemos referido a la intención didáctica que sostiene la pareja conformada por un maestro y un discípulo.

El otro intento que perseguimos fue el reconocimiento de las Musas, las Helíades y la Musa, en los tres autores respectivamente, para ver cómo se hilvana la ecuación saber-poder-verdad en esta esfera de pensamiento, en la que aún la cartografía que separa y delinea los confines de la poesía didáctica y la filosofía no está cristalizada en tópoi compartimentados. En esas "sendas embrolladas", familiares a la genealogía nietzscheana como modo de abordar la complejidad de lo real, las relaciones entre filosofía y poesía constituyen un tópico de problematización e inquietud ${ }^{14}$. Varios han sido quizás los verbos que han sostenido el presente trabajo: transmitir, decir, hablar y oír. Dos han sido los dominantes, ya que, tensionando los juegos de poder, unos hablan porque conocen el mensaje

\footnotetext{
14 Ver Foucault, 1979.
} 
que se debe referir y otros oyen para, en la línea de ese mensaje, conocer aquello que fue en el principio.

\section{Bibliografía}

BERNABÉ PAJARES, Alberto. Fragmentos presocráticos. De Tales a Demócrito. Madrid: Alianza, 2008.

COLLI, Giorgio. El nacimiento de la filosofía, Barcelona: Tusquets, 1994.

COLOMBANI, María Cecilia. Hesíodo. Una introducción crítica. Buenos Aires: Santiago Arcos, 2005.

COLOMBANI, María Cecilia, Hesíodo. Arqueología y Discurso. Una aproximación arqueológica. Mar del Plata: Editorial de la Universidad de Mar del Plata, 2016.

CORDERO, Néstor Luis. Siendo se es. La tesis de Parménides. Buenos Aires: Biblos, 2005.

CORDERO, Néstor Luis. La invención de la filosofía. Una introducción a la filosofía antigua. Buenos Aires: Biblos, 2008.

DETIENNE, Marcel. Los maestros de verdad en la Grecia Arcaica. Madrid: Taurus, 1986.

ELIADE, Mircea. Mito y realidad. Colombia: Labor, 1991.

FOUCAULT, Michel. El orden del discurso. Barcelona: Tusquets, 1983.

FOUCAULT, Michel. Nietzsche, la historia, le genealogía en Microfísica del poder0 Madrid: Ediciones La Piqueta, 1979.

GERNET, Louis. Antropología de la Grecia Antigua, Madrid: Taurus, 1981.

GIGON, Olof. Problemas fundamentales de la filosofía griega. Buenos Aires, Compañía General Fabril Argentina, 1962.

GIGON, Olof. Los orígenes de la filosofía griega. Buenos Aires: Gredos, 1985.

HESÍODO, Obras y fragmentos. Traducción y notas de Aurelio Pérez Jiménez y Alberto Martínez Díez. Madrid: Gredos, 2000.

MONDOLFO, R. El pensamiento antiguo, Buenos Aires, Losada, 1980.

VERNANT, J.-P. Mito y religión en la Grecia Antigua, Barcelona, Ariel, 2001. 